\title{
A Revista História Hoje e os 60 anos da Anpuh-Brasil
}

\author{
The História Hoje Journal and \\ the 60 Years of Anpuh-Brasil
}

Para celebrar os sessenta anos da Associação Nacional de História (Anpuh-BR), temos o prazer apresentar um dossiê da Revista História Hoje que aborda os percursos de nosso periódico, entre os anos 2003 e 2021, como locus de referência para a publicação das pesquisas e experiências práticas da área de ensino de História no Brasil.

A ideia deste dossiê vem com o compromisso de fazer uma reflexão crítica acerca dos inícios da RHHJ e do seu processo de consolidação por meio da sua agenda temática e política editorial contemplando os desafios, problemas e abordagens da História no contexto da educação básica e formação e prática dos/as professores. E aqui agradecemos mais uma vez o aceite dos colegas Margarida Maria Dias de Oliveira e Itamar Freitas de Oliveira de coordenarem este número especial.

Nesse sentido, a história da Revista se encontrou com eventos significativos na nossa área, como revolução de abordagens e enredos a partir da implantação das leis n. 10.639/03 e 11.645/08, que instituíram o ensino de História e cultura africanas, afro-brasileiras e indígenas na educação básica; as contendas em torno das reformas curriculares nos cursos de História e a política de formação de professores; as instigantes experiências e ideias potencializadas a partir do programa institucional de bolsas de iniciação à docência (PIBID) na interface escola e cursos de licenciaturas; as demandas, polêmicas e debates acerca do Programa Nacional do Livro Didático (PNLD); o Plano Nacional de Educação e os enfrentamentos da agenda conservadora contra as pautas identitárias e de gênero; as disputas de narrativas em torno da Base Nacional Comum Curricular (BNCC), em especial o documento História; as lutas e denúncias 
contra os movimentos de cerceamento da liberdade de ensino-aprendizagem dos/as professores/as, as arbitrariedades e imposições da Reforma do Ensino Médio afetando drasticamente o espaço das Humanidades em seu currículo; a supressão de direitos sociais por uma "política ideológica" dos governos pós-impeachment, ou melhor, pós-golpe de 2016, que fraturou as estruturas frágeis da democracia brasileira em construção desde a Constituição de 1988. Podemos dizer que, nesse período, assim como a Anpuh-Brasil e suas regionais, a RHHJ não passou indiferente a esses fatos, ora como protagonista, como espaço de discussão ou fórum, ora como objeto das contendas e demandas da área de História no Brasil contemporâneo.

A campanha pela regulamentação da profissão de historiador/a, uma pauta histórica da entidade, também ocupou as páginas da nossa Revista, com ênfase no que se despontava na sua identidade e perfil dos profissionais da educação básica. Em 2020, apesar de toda agenda conservadora e desmandos do atual governo, a Anpuh-BR conseguiu mobilização emblemática para a aprovação da lei de regulamentação da profissão de historiador/a no Congresso Nacional, por meio de seus sócios, formadores de opinião na mídia e lideranças políticas de diferentes partes do país, entre deputados/as federais e senadores/as.

Também não ficou à margem das pautas da $\mathrm{RHHJ}$ as questões sensíveis em torno das violências praticadas contra minorias nos país: indígenas, afrodescendentes, populações tradicionais, mulheres, as comunidades LGBTQIA+, as crianças e trabalhadores em condições análogas à escravidão, os ativistas pelas pautas ambientais e dos direitos humanos.

Nessa caminhada de sessenta anos da entidade, passando por lutas contra a ditadura civil-militar, as campanhas pela redemocratização do país e as lutas pelos direitos sociais e enfrentamento dos desafios, dilemas, demandas e expectativas dos profissionais da História, a pauta do ensino de História alcançou seu lugar de importância nos fóruns e eventos nacionais e regionais, dossiês e artigos na Revista Brasileira de História, nos grupos de trabalho Ensino de História e Educação, na articulação das pautas da educação, ensino de História e formação de profissionais de História nos cursos de graduação por parte da segunda secretaria da Diretoria Nacional e na criação da Revista História Hoje. Poderíamos aqui elencar uma série de projetos e ações da entidade, em diferentes esferas - do regional ao nacional, tendo o ensino de História na sua 
pauta. No caso do biênio que se encerra, temos a celebrar a abertura do primeiro edital do Prêmio Ensino de História - Déa Fenelon, para práticas pedagógicas em História executadas no quadriênio 2016-2020 por professores/as da educação básica nas instituições de ensino públicas.

$\mathrm{E}$, mesmo diante das lutas cotidianas contra os retrocessos da agenda antidemocrática do atual governo e a tragédia humana em decorrência da Covid-19 - que só no Brasil ultrapassou a vergonhosa marca de mais de 500 mil vítimas fatais, não perdemos nosso compromisso com a produção e circulação do conhecimento histórico, na defesa dos direitos humanos e na diversidade das formas de pensar, sentir e estar no mundo, sem perder de vista nossos compromissos inegociáveis com a ética, a ciência e a vida. E aqui as muitas vozes que constituem o mosaico da Anpuh-BR e, também, da RHHJ estão presentes, em estado de sentinela para que não mais ocorra "democracia, volver!”.

Entre Cuiabá e Florianópolis, julho de 2021.

Renilson Rosa Ribeiro Editor - RHHJ (2019-2021)

Mônica Martins da Silva Editora - RHHJ (2021-2023) 